\title{
Parricide and Polemic
}

An Encounter with:

Mehdi Belhaj Kacem, Transgression and the Inexistent: A Philosophical Vocabulary. Trans. P. Burcu Yalim. London: Bloomsbury, 2015. Suspensions: Contemporary Middle Eastern and Islamicate Thought. $256 \mathrm{p}$.

\section{MaXwell KenNel}

Although Mehdi Belhaj Kacem is not often included in lists of contemporary French philosophers that appear in English-language works on the subject - lists that privilege names like Badiou, Laruelle, Malabou, Stiegler, Meillassoux, and now Garcia-the appearance of his first translated book may indeed grant him a place on those lists. Until now, the North American reader of French philosophy will have only seen a substantial treatment of Kacem in the work of Alexander Galloway (whether through his CTheory review of Kacem's L'espirit du nihilisme or in his lectures at the Public School in New York). Apart from Galloway's work however, only a popular article in The New Inquiry provides an English introduction to Kacem's work.

With only a few witnesses, Kacem's work is still mysterious. But that is set to change, for better or for worse, with the appearance of Transgression and the Inexistent. Kacem is a Tunisian-born French philosopher who has authored at least twenty books, from the novels of his youth to his more recent philosophical system. Also an award-winning actor, at least for his part in the film Wild Innocence (2001), Kacem is certainly an unconventional thinker who challenges established ways of evaluating philosophers and their philosophies. Intriguing aspects of his biography include his lack of significant graduate education, his public break-up with his former mentor Alain Badiou, and vague references to his life of poverty in central France (as the back cover blurb by Graham Harman indicates). Certainly the lives of French philosophers continue to be an object of fascination in the more mundane milieu of North American philosophy. However, in this view one is tempted to separate the life from the work of a philosopher like Kacem, and to do so in such a way that takes up a position of judgment from high above both philosophy and its biography. However, at this juncture in the history of philosophy when 
Heidegger's Schwarze Hefte are weakening the divide between his particular life and work, perhaps it bears keeping in mind the fact that much of the performative work of philosophy rests on the inseparability of philosophy and biography. With that in mind, let us stage a book encounter with Transgression and the Inexistent, and in doing so try to judge this strange and frustrating work by its own standard, rather than by the established criteria for a "good" work of philosophy.

Transgression and the Inexistent is a difficult book to place in a genre. It is not a monograph, or a study of particular authors; and it is not a linear work in which the parts of the book move teleologically toward a conclusion. Instead, the author calls it a "bestiary," a "vocabulary," or a "lexicon" (vii-viii); but it is more and less than these things. Transgression and the Inexistent professes to be a summary of Kacem's thought to date, promising a summary of many of his major works, and a continuation of his philosophical system: "the System of Nihilism." The book appears in the Bloomsbury series "Suspensions: Contemporary Middle Eastern and Islamicate Thought" alongside titles that explicitly address Islam in Iran and Turkey, and explore themes such as cosmopolitanism and violence. Contrary to the themes of the series in which it appears, the reader of Transgression and the Inexistent will be hard pressed to find significant reference to, much less focused work on, Islamicate thought or the Middle Eastern context.

Transgression and the Inexistent is divided into twenty-six entries, a few of which are one-line references to other entries ("Woman," "Man," "Singularity," etc.), each of which are concerned with a different topic relating to Kacem's system (as well as an appendix called "Propreptic to Being and Sexuation"). The Foreword serves as a biographical introduction to Kacem and his many books, both situating Transgression and the Inexistent in his corpus and acclimating the reader to his very personal voice. The Foreword begins with the promise that the book will "recapitulate eight years of intellectual construction work sedimented into a system," while summarizing the many scholarly books in his oeuvre (vii); and it is to this promise that I will hold Transgression and the Inexistent in this review. The rest of the Foreword is an exercise in intellectual autobiography, and in it Kacem states that: he was approached to write the book by his friends and the publisher (vii-viii); he has no university training above the baccalauréat (x); he lives in a "sometimes Dickensian material precariousness" (xi); and finally that during the writing of Transgression and the Inexistent he did not open any of his previous books so that he would have to rely upon his own memory of his system (xii-xiii). This decision in particular will be considered in evaluating whether or not the book achieves its self-professed aim to summarize Kacem's system. 
The other topic that the Foreword pursues is that of Kacem's present rejection of Alain Badiou's person and work (ix). Periodizing Kacem's work in a very noticeable way, the parricidal break with Badiou divides Kacem's work in a very clear fashion, distinguishing the works he wrote before his time as Badiou's student from the works he wrote after, so much so that his most Badiou-centric work-Événement et répétitionis not included in his list of books supposedly summarized in Transgression and the Inexistent.

In the first entry of the book, titled "Affect," Kacem ruminates on the problem of evil and the human/animal relationship, leaning on the yet undefined terms of "appropriation" and "expropriation" (2-4). In the second entry, Kacem then defines his use of the term "Appropriation" as the coincidence of techne and mimesis, stating that "Man [sic] is an ultraappropriative animal because he is the animal of protoscientific astuteness: of technics and imitation" (7). This codetermining of the human by techne and mimesis, indicated by the term "appropriation," is what Kacem sees as his contribution to "the great German metaphysics of time and space" (7).

This initial ontological claim demonstrates Kacem's debt to both Badiou and Heidegger. In straightforward accordance with the titles of their major works the former thinker provides Kacem with a starting point for the relationship between being and event, and the latter thinker provides Kacem with a starting point for the relationship between being and time. However, it would be simplistic to say that Kacem draws straightforwardly from either Badiou or Heidegger in Transgression and the Inexistent or in his more detailed work in L'esprit du nihilisme. First of all, it is important to note that while drawing upon their work, Kacem ruthlessly attacks both Badiou's Maoism and Heidegger's Nazism. Although we are accustomed to hearing about Heidegger's political and personal moral failures, we are less accustomed to hearing critical comments about Badiou's open endorsement of the Cultural Revolution (especially from those who use his work constructively). Despite his critiques, Kacem seems to skirt some of the problems with implementing aspects of the work of Badiou and Heidegger by tempering their work through other thinkers. As a correlate to Badiou, Kacem draws upon the work of Giorgio Agamben, and as a correspondent to Heidegger Kacem draws upon the little-known thinker Reiner Schürmann (author of the magisterial Broken Hegemonies).

Returning to Transgression and the Inexistent, in the entry titled "Art" the conjunction of techne and mimesis reappears in a different form when Kacem states that "the SoN [System of Nihilism] shows that originary mimesis is nothing other than Science itself; i.e., techne in its infancy" (15). Imitation results in techne. Kacem's examples begin with helpful illustrations ("Agriculture is nothing other than the imitation of food gathering."), but continue into more complicated territory with the 
claim that politics "is nothing other than the imitation of Science" (15). The redoubling and repetition of mimesis continues in Kacem's system, eventually giving rise to a "dialectical mechanism" (16). Addressing the issue at hand in the entry, Kacem identifies art with catharsis, and joins catharsis with techne and mimesis to create a tripartite schema. The cathartic nature of art, combined with the redoubling of mimesis, leads Kacem to develop his theory of transgression. The cathartic nature of art is tied together with the surpassing Aufhebung of transgressive overcoming: "not only must one surpass incessantly, but this surpassing must be surpassed, and this surpassing of the surpassing must be surpassed, etc." (16). This repetition of surpassing and transgressing established boundaries finds many political and cultural manifestations for Kacem, from political revolutions (in descending order of moral failure from the French Revolution to May 1968 to the Cultural Revolution), to the ongoing cultural overturnings of sexism and homophobia (17). Titled "Aufhebung," the following entry continues the association of dialectical overcoming with catharsis (23), and then further defines techne as the confluence of catharsis, mimesis, and Aufhebung (25).

In the entry titled "Desire" Kacem returns to the themes of the first entry. He states that "Desire is the propensity of the being [l'étant] to appropriation," and suggests that this type of desire is what separates humans from animals (28). Referring obliquely to some of his published works, he piles digression upon digression and eventually loses the plot of the title of the entry. Continuing in his promised effort to outline his philosophical system, Kacem leans heavily on references to works he has written, rather than providing descriptions of the contents of those works, eventually ending the entry with the unassigned description: "A philosophy, metaphysically switch and queer, but nevertheless dressed to the nines and a trifle dandy" (36). Despite its frustrating succinctness, this description of Kacem's system seems accurate given his alternation between dominating exercises of epistemological power (self-avowedly grandiose and megalomaniacal claims), and submissive crediting of other thinkers (such as his confessed debt to Philippe Lacoue-Labarthe). The stylistic flourishes of Kacem's system indeed seem "dressed to the nines" although it is hard to separate real philosophical insight from fashion throughout Transgression and the Inexistent.

In the next entry, titled "Ontological differend," addresses his earlier concept of expropriation by associating it with many other concepts (singularity, transgression, precariousness), but does not directly define his use of it (37). In the entry titled "Event" Kacem continues explicating his system, stating that "Techne is therefore, quite simply, catharsis of nature" (46). In the entry titled "Expropriation" Kacem associates the term with the marginalized and dispossessed, but stops short of providing the reader with even a thematic connection with the major terms of his system. 
Kacem's entry titled "History," however, does pick up where the string of conceptual conjugations leaves off in the entry on the event. For Kacem, history is determinant of humans because humans are "the animal[s] of technomimetic appropriation" (58).

As the entries continue several points of interest appear. For example, the entry titled "Irony" includes some brief critical remarks on the Tiqqun collective and their theory of bloom (74), and the entry titled "Play" equivocates the violence of sport with the violence of war (78). Although the section on play includes some interesting reflections on Badiou and evil, and despite the fact that the entry titled "Catharsis" does revisit some of the themes prominent in the first few entries, the interesting conceptual associations suggested early in the book (techne, mimesis, Aufhebung, catharsis) become more and more difficult to both find and piece together, leading one to suspect that readers of contemporary French philosophy would be better off consulting Bernard Stiegler on the question of techne and René Girard on the theme of mimesis, than relying on Kacem for a framework within which to understand these concepts.

So has Transgression and the Inexistent followed through on its promise to helpfully summarize Kacem's many French books for the English reader? My assessment is that it has not. Kacem's choice not to open any of his previous books in the process of writing Transgression and the Inexistent strikes me as something that has hindered rather than helped his goals. His self-review of his own Manifeste antischolastique which includes a mysterious graph and some further biographical reflection (41-42), his statement that "Ironie et vérite is the kind of book I somewhat regret having had published by a 'small' publisher" (67), and his references to his yet unpublished works (127), do not amount to anything close to a summary of his work, much less an introduction.

And so, in light of this negative assessment, it is worth briefly reflecting on the place of "difficult theory" in contemporary French philosophy, if only in the pursuit of staging an encounter with this text that is sensitive to its context. It is difficult to know how to evaluate a work of theory, given that it is a particular genre within French philosophy that rejects the often stifling standards of scholarly rigor that dominate AngloAmerican philosophy. The type of philosophical writing that Kacem engages in is somewhere between performative artistic creation, and philosophical system building. Holding a measuring stick up to works of theory like Kacem's Transgression and the Inexistent is difficult because it risks imposing a standard on the work that is not its own, and under which it was not written. Accordingly, the review above has restricted itself to judging Kacem's book against its own explicitly stated goals. That said, the temptation to harshly evaluate works like Transgression and the Inexistent (perhaps by condemning how much patience is demanded of the 
reader) comes from a sensibility that deserves to be unpacked. On one hand the difficulty of a theory can increase its reward when one comprehends a dense and convoluted text after taking time to learn its language and history and then spending time closely reading the text. On the other hand, difficult theories can have a far greater proportion of difficulty than reward, evident when after learning the context and terms of a text, and spending a great deal of time with it, one is left with very little conceptual beauty to behold or descriptive edification to grasp. To hold works like Kacem's to the standard of clarity and syllogistic argumentation would be to misunderstand the genre in which his book falls. However, to completely avoid expecting clarity and coherence from Kacem would also be to take refuge in another easy extreme. In addition to not being a helpful summary of Kacem's work to date, Transgression and the Inexistent certainly fails on the level of conceptual clarity and coherence. However, it remains to be seen whether the same can be said for Kacem's philosophical system as a whole. However, for an evaluation of the breadth of Kacem's system the North American reader of French philosophy may have to wait for a secondary work capable of doing what Transgression and the Inexistent could not.

\section{Works Cited}

BelHaJ Kacem, Mehdi. Événement et répétition: digest du séminaire. Foreword by Alain Badiou. Paris: Tristram, 2004.

—. Ironie et vérité. Paris: Nous, 2009.

_. L'esprit du nihilisme, une ontologique de l'Histoire. Paris: Fayard, 2009.

- Transgression and the Inexistent: A Philosophical Vocabulary. Trans. P. Burcu Yalim. London: Bloomsbury, 2015. Translation of the expanded and corrected version: La transgression et l'inexistant: un vocabulaire philosophique. Paris, META, 2015.

Fox, Max. "Not the One" The New Inquiry. Vol. 11, 2012. http://thenewinquiry.com/essays/not-the-one/

Galloway, Alexander. "The Spirit of Nihilism." CTheory, 2009. http://www.ctheory.net/articles.aspx?id=616

SCHÜRMANN, Reiner, Broken Hegemonies. Trans. R. Lilly. Bloomington: Indiana University Press, 2003. 